\title{
Linking Halal Food Certification and Business Performance
}

Ab Talib, Mohamed Syazwan; Chin, Thoo Ai ; Fischer, Johan

Published in:

British Food Journal

DOI:

10.1108/BFJ-01-2017-0019

Publication date:

2017

Document Version

Peer reviewed version

Citation for published version (APA):

Ab Talib, M. S., Chin, T. A., \& Fischer, J. (2017). Linking Halal Food Certification and Business Performance. British Food Journal, 119(7), 1606-1618. https://doi.org/10.1108/BFJ-01-2017-0019

\section{General rights}

Copyright and moral rights for the publications made accessible in the public portal are retained by the authors and/or other copyright owners and it is a condition of accessing publications that users recognise and abide by the legal requirements associated with these rights.

- Users may download and print one copy of any publication from the public portal for the purpose of private study or research.

- You may not further distribute the material or use it for any profit-making activity or commercial gain.

- You may freely distribute the URL identifying the publication in the public portal.

Take down policy

If you believe that this document breaches copyright please contact rucforsk@kb.dk providing details, and we will remove access to the work immediately and investigate your claim. 


\title{
Linking Halal Food Certification and Business Performance
}

\author{
Mohamed Syazwan Ab Talib \\ Faculty of Management \\ Universiti Teknologi Malaysia \\ 81310 Johor Bahru, Malaysia \\ msyazwan79@live.utm.my \\ Thoo Ai Chin \\ Faculty of Management \\ Universiti Teknologi Malaysia \\ 81310 Johor Bahru, Malaysia \\ Johan Fischer \\ Department of Social Sciences and Business \\ Roskilde Universitet \\ 4000 Roskilde, Denmark \\ Appeared in: \\ British Food Journal, Vol. 119 No. 7 \\ DOI: 10.1108/BFJ-01-2017-0019 \\ Publisher: \\ Emerald Publishing Limited
}




\section{Linking Halal Food Certification and Business Performance}

Purpose: The purpose of this empirical research is to explore the relationship between Halal food certification and business performance. This study argues that Halal food certificate implementation positively influences business performance.

Design/methodology/approach: A total of 210 Halal certified food manufacturing companies in Malaysia participated in the study. Data were gathered through a structured questionnaire and were analysed using partial least squares structural equation modelling technique.

Findings: The study proved that Halal food certification has a positive relationship with operational performance. Additionally, operational performance mediates the relationship between Halal food certification and financial performance. Altogether, this signifies that Halal food certificate implementation positively influences business performance.

Practical implications: By linking Halal food certification and business performance, managers may be aware of the significant role of Halal food certification in influencing operational and financial performance. It would entice more food companies to become Halal certified that opens up an opportunity to a lucrative Halal food industry. It also empirically justifies that a religionbased food certification has the ability to influence business performance, consistent with other established food standards such as ISO 22000 or HACCP.

Originality/value: Although numerous studies have concentrated on well-established food certifications, the expanding Muslim population, rising demand for Halal food, and lucrative Halal food market have raised the attention on Halal food certification research among academicians and practitioners. This research is able to highlight the importance of implementing Halal food certification among food companies as it could potentially lead to superior business outcomes.

Keywords: Halal; Halal food; Halal food certification; food manufacturer; business performance; PLS-SEM

Article Classification: Research Paper 


\section{Introduction}

In recent years, there has been an increasing interest in Halal food certification, particularly from the consumers' perspectives. Research on Halal food certification often focused on consumer purchase intentions or behaviours (Aziz and Chok, 2013), willingness-to-pay (Verbeke et al., 2013), awareness or perceptions (Haque et al., 2015), and confidence level (Mohamed et al., 2013). The reasons behind the rising attention on Halal food certification research could be attributed to the heightened awareness, concern, and knowledge on Halal food among consumers.

Despite the growing interests, the scope of Halal food certification research is rather imbalance and the disparity is shown by the limited literature on Halal food production research (Talib et al., 2016a). Research that studied the upstream parties of the Halal food chain (i.e suppliers, manufacturers, producers, retailers) remained scarce. These lack of Halal food production research, however, commonly studied the attributes, reasons, readiness, and perceptions on Halal food certification (Rafiki and Wahab, 2016; Rahman et al., 2016; Talib et al., 2015; Badruldin et al., 2012; Marzuki et al., 2012). Scholars have yet to probe a more significant investigation on Halal food certification, in particular, its association with improved business performance.

Undoubtedly, food companies have begun to implement Halal food certification on a global scale (Lever and Miele, 2012). International food companies such as McDonald's and Nestle have extensively implemented and introduced Halal certification into their operations and productions (Fischer, 2016 and 2012). According to Talib et al. (2015), this phenomenon is caused by the relentless consumer pressure and the profound food industry competition. However, the pursuit of Halal food certification could be futile if firms are unable to enjoy the advantages from being certified. More precisely, the extensive efforts to implement Halal food certification are deemed impractical if it does not contribute to enhanced business performance. Therefore, this raises the question whether Halal food certificate implementation can influence business performance or not?

Considering the uneven scope of Halal food certification research and the limited understandings on Halal food production research, this paper attempts to link previously unconnected variables of Halal food certificate implementation and business performance. Hence, the purpose of this study is to explore the relationship between Halal food certification and business performance. This study aims to obtain data which will help to address the Halal food certification research gaps. Understanding the link between Halal food certificate implementation and business performance will benefit food companies in terms of enhanced knowledge, encourage certified firms to remain verification, and potentially entices non-certified firms to implement Halal food certification. 
This paper first gives a review of the relevant literature on Halal food certification and business performance. It will then go on to discuss the development of research framework and proposing several research hypotheses. Subsequently, the paper then presents the methodology used in this research. Accordingly, the results are analysed and the findings are then discussed and interpreted. Lastly, the paper concludes by highlighting the summary, limitations, and several recommendations for future studies.

\section{Literature Review}

Halal food certification, either in the form of license, logo, seal, or stamp, is a form of identification to inform users that a food product is sourced, produced, and distributed in accordance with the strict Islamic standards. Throughout this paper, the term Halal food certification refers to Riaz and Chaudry's (2004, p. 170) definition that it is "a document issued by an Islamic organisation certifying that the products listed on it meet Islamic dietary guidelines, as defined by [a specific] certifying agency".

The connection between Halal food certification and food safety and quality is expected because food manufacturers must undergo a series of stringent and exhaustive orientations, inspections, and corrective measures before certification is granted. Past research demonstrated that Halal food certification is a type of food safety certification, consistent with established standards, for instance, the HACCP, GMP, or ISO 22000 (Demirci et al., 2016; Talib et al., 2015; Nawi and Nasir, 2014; Kohilavani et al., 2013).

There is a large number of published studies (Chen et al., 2015; Escanciano and SantosVijande, 2014; Kafetzopoulos and Gotzamani, 2014; Macheka et al., 2013; Karaman et al., 2012; Mensah and Julien, 2011) that connect food safety certification with improved business performance. For instance, Chen et al. (2015) explained that food companies in New Zealand experienced improved market performance and better relationship with customers. Meanwhile, Escanciano and Santos-Vijande (2014) revealed that ISO 22000-certified companies in Spain experienced both internal and external benefits.

The past studies reviewed thus far provide evidence that food certification, in general, has the ability to improve business performance. However, past research on Halal food certification have sporadically and disjointedly specified the benefits of implementing Halal food certification. Scholars have yet to comprehensively link Halal food certification and business performance. Table 1 elucidates the terse and disperse association between Halal food certification and business performance. 
As shown in Table 1, it is clear that scholars have the understanding and confidence that, in principle, Halal food certification could potentially influence business performance. Yet, studies that justify the link remains untested while empirical evidence is lacking. Nevertheless, it gives the opportunity for this study to comprehensively study the said relationship and reinforce the notion.

Table 1: Studies Mentioning of Halal Food Certification and Business Performance

\begin{tabular}{|c|c|c|}
\hline Author (Year) & Quotation & Type of Performance \\
\hline $\begin{array}{l}\text { Talib et al. } \\
(2016 b)\end{array}$ & $\begin{array}{l}\text { "[Halal certification] might have implications } \\
\text { on the growth of the consumer base and } \\
\text { increase the number of customers, hence } \\
\text { increasing the revenue for firms" } \\
\text { "... Halal certification as a mechanism to } \\
\text { improve organisational performance, } \\
\text { particularly logistics performance" }\end{array}$ & $\begin{array}{l}\text { - } \text { Market share } \\
\text { - } \text { Increase number of } \\
\text { customers } \\
\text { - Increase revenue } \\
\text { - Logistics } \\
\text { performance }\end{array}$ \\
\hline $\begin{array}{l}\text { Nawi and } \\
\text { Nasir (2014) }\end{array}$ & $\begin{array}{l}\text { "...[Halal certification] ensured better product } \\
\text { handling, and respondents were more } \\
\text { confident of [Halal certified] food products" }\end{array}$ & $\begin{array}{l}\text { - } \text { Better management } \\
\text { Enhanced consumer } \\
\text { confidence }\end{array}$ \\
\hline $\begin{array}{l}\text { Noordin et al. } \\
(2014)\end{array}$ & $\begin{array}{l}\text { "...Halal product certification is the } \\
\text { prerequisite for entering the global Halal } \\
\text { market..." } \\
\text { "...Halal certificate can help [organisations] } \\
\text { meet the Halal requirements ... in turn can } \\
\text { help the business expands its marketplace to } \\
\text { increase its sales and revenue" }\end{array}$ & $\begin{array}{l}\text { - } \text { Ease market entry } \\
\text { - Assist market } \\
\text { expansion } \\
\text { - Potentially increase } \\
\text { - } \text { sales } \\
\text { - Impact on revenue }\end{array}$ \\
\hline $\begin{array}{l}\text { Aziz and Chok } \\
(2013)\end{array}$ & $\begin{array}{l}\text { "...Halal certification has a significant positive } \\
\text { relationship with intention to purchase halal } \\
\text { product" }\end{array}$ & $\begin{array}{l}\text { - Affects customer } \\
\text { decision }\end{array}$ \\
\hline $\begin{array}{l}\text { Marzuki et al. } \\
\text { (2012) }\end{array}$ & $\begin{array}{l}\text { "...restaurant managers in Malaysia have their } \\
\text { own perspectives toward halal certification } \\
\text { that contributes to the growth of food } \\
\text { marketing and tourism industry" } \\
\text { "...it is definitely an indication that the } \\
\text { certificate is perceived to have an impact on } \\
\text { customer trust and return visits" }\end{array}$ & $\begin{array}{l}\text { - Market or industry } \\
\text { growth } \\
\text { - Maintain customer } \\
\text { trust } \\
\text { - Customer retention }\end{array}$ \\
\hline
\end{tabular}


Table 1: Studies Mentioning of Halal Food Certification and Business Performance (continued)

\begin{tabular}{|c|c|c|}
\hline Author (Year) & Quotation & Type of Performance \\
\hline $\begin{array}{l}\text { Tieman et al. } \\
\text { (2012) }\end{array}$ & $\begin{array}{l}\text { "...Halal has impact on the financial result for } \\
\text { producers of halal sensitive product" }\end{array}$ & $\begin{array}{l}\text { - } \text { Financial } \\
\text { performance }\end{array}$ \\
\hline $\begin{array}{l}\text { Noordin et al. } \\
\text { (2009) }\end{array}$ & $\begin{array}{l}\text { "...Halal certification and logo are the } \\
\text { important elements in gaining global market } \\
\text { shares and retaining customers" }\end{array}$ & $\begin{array}{l}\text { - Market share } \\
\text { expansion } \\
\text { - } \text { Customer retention }\end{array}$ \\
\hline $\begin{array}{l}\text { Abdul et al. } \\
(2008)\end{array}$ & $\begin{array}{l}\text { "...[Halal] certification is able to promote } \\
\text { confident, trust and satisfaction amongst } \\
\text { their consumers" }\end{array}$ & $\begin{array}{l}\text { - Enhanced consumer } \\
\text { confidence } \\
\text { - Consumer } \\
\text { satisfaction }\end{array}$ \\
\hline
\end{tabular}

\section{Research Framework and Hypotheses}

One of the established theory for assessing business performance is the Resource-based View (RBV) theory. In a seminal work linking firm resources and sustained competitive advantage, Barney (1991) explained that any form of resources made available to a firm, if used effectively and efficiently, could lead to favourable business outcomes. The foundation of the RBV theory is based on the assumption that a firm's tangible or intangible attributes, if correctly executed, could possibly create inimitable, rare, non-substitutable, and valuable possessions. The ability to have resources of such natures may eventually benefit a firm with sustained competitive advantage.

Based on Barney's (1991) concept of RBV, this paper argues that certification is essentially a type of resources, deployed by food companies as a tool to achieve sustainable competitive advantage. We argue that food companies are aggressively producing and selling homogeneous products, whilst competing in an extremely competitive, highly volatile, and saturated market. Thus, food companies are exploring ways to stand out from the competition and strive to become the market leader by offering unique products to the consumers. Therefore, food companies are emphasising on securing Halal certification, which signals and enable them in offering better products to the consumers. 
To support the argument, evidence from past research indicated that firms utilised various types of certification as an instrument to achieve desired business outcomes (Talib et al., 2016b; Fikru, 2014; Kafetzopoulos and Gotzamani, 2014; Sampaio et al., 2009; Chow-Chua et al., 2003; Sum et al., 2001). Likewise, Talib et al. (2016b, p. 470) explained that "apart from implementing Halal certification as a tool to gain business legitimacy, industry practitioners use Halal certification as a mechanism to improve organisational performance". Hence, this paper postulates the following hypotheses:

H1: $\quad$ There is a positive relationship between Halal food certification and operational performance.

H2: $\quad$ There is a positive relationship between operational performance and financial performance.

In addition, business performance is generally observed as the integration between two notable performance measures, specifically the operational and financial performances (Feng et al., 2008). In the context of certification research, scholars concurred that certification can influence both operational and financial performance. However, for the purpose of this study, we assume the study done by Psomas et al. (2013) that operational performance mediates the relationship between Halal food certification and business performance. This research maintains that, logically, implementing Halal certification per se would not instantaneously influence financial performance as it requires the proper and comprehensive operational executions. The success obtained from well-enforced operations would then potentially influence financial performance. Therefore, this paper postulates that:

H3: Operational performance mediates the relationship between Halal food certification and financial performance.

The framework of this research is depicted in Figure 1. Therefore, drawing from the review of relevant literature and applying the RBV theory as the basis for a theoretical framework, this paper posits that Halal food certificate implementation positively influences business performance. 


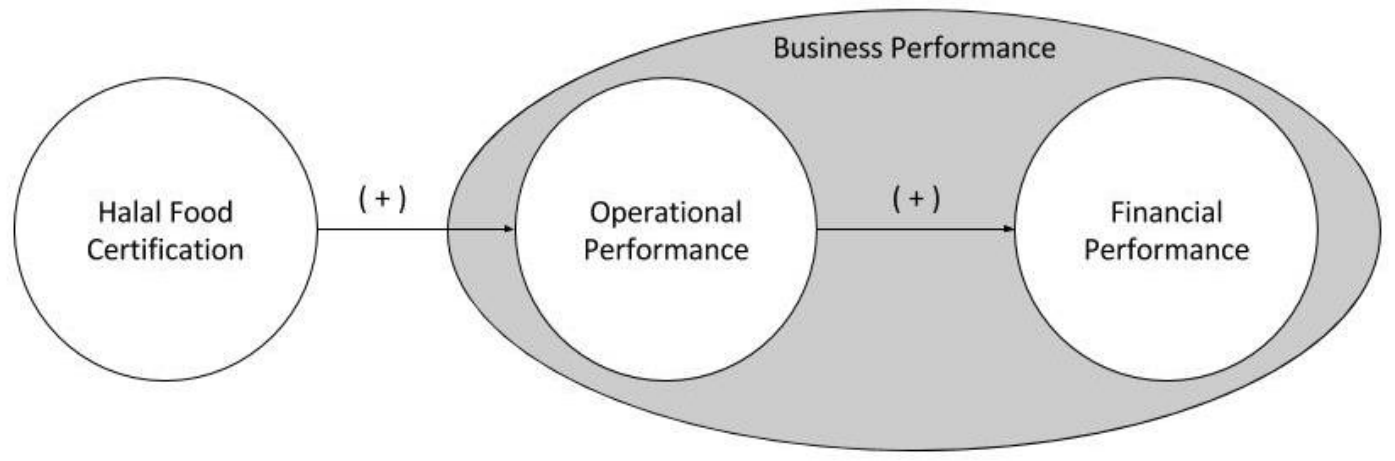

Figure 1: Proposed Theoretical Framework

\section{Research Methodology}

As the study aims to assess the link between Halal food certification (MS1500) and business performance, it applies a quantitative research design and employs a survey methodology. Data were collected using a self-administered questionnaire. The questionnaire was designed based on the review of past literature and sourced from several published instruments that were akin to the present study.

The questionnaire was divided into three parts (Part A, B, and C). Part A contains 25 items relating to the components of Halal food certification, while Part $B$ consists of 12 items on operational (eight items) and financial performances (four items). Part $C$ involves five items designed to gather the respondents' demographic information. For Part A and B, a five-point Likert scale was used, ranging from 1 (strongly Disagree) to 5 (strongly agree). In Part C, nominal scales were used to solicit information on personal and organisation backgrounds. Prior to data collection, the questionnaire was pre-tested to check the wording, sequencing, clarity, relevance, adequacy, and the overall structure.

The population for this study consisted of the MS1500-certified food manufacturing companies in Malaysia. The MS1500 certification and the Malaysian Halal food industry were chosen on the basis that the country is the pioneer and leader in the Halal food industry and its certification is highly recognised (Rahman et al., 2013). The sampling population was derived from the Federation of Malaysian Manufacturers' directory on Halal food. A purposive judgemental sampling technique was applied and managerial personnel overseeing the MS1500 procedures were identified as the unit of analysis. The selection is based on the understanding that managerial personnel (i.e. business owner, CEO, quality control managers, senior managers) have comprehensive knowledge on operation and production and simultaneously command influential role in an organisation (Zailani et al., 2015). 
Once data were gathered, the correlational relationship between Halal food certification and business performance were examined using partial least squares structural equation modelling (PLS-SEM) technique. A PLS-SEM technique was chosen for data analysis because this approach is suitable for an exploratory research where the substantial understanding and information is rather limited (Hair et al., 2011). Moreover, PLS-SEM is a latent variable modelling technique that simultaneously observes multiple variables and recognises measurement errors (Hair et al., 2014a). Besides, scholars in the field of business research have widely applied PLS-SEM as it has a comparatively high statistical power to analyse complex structural equation models with multiple constructs (Hair et al., 2014b, 2012a, 2012b). The SmartPLS 2.0 application (Ringle et al., 2005) was used for data analysis.

\section{Results and Analysis}

\subsection{Demographic Profile}

Initially, a total of 500 self-administered questionnaires were distributed among MS1500 Halal certified food manufacturing companies in Malaysia. However, only 210 usable questionnaires were returned and this gave a response rate of 42 percent. Out of the 210 food manufacturing companies participated in this study, a majority of them are fully Malaysianowned corporations (68.1 percent).

Furthermore, in terms of the size of operation, a large percentage of the respondents had 6 to 75 employees (43.3 percent). This figure indicates that majority of the respondents were smallsized food manufacturing companies. Collectively, 69.5 percent of the respondents were smallmedium enterprises (SME). Additionally, more than half of the respondents had been established for 11 years or more (53.3 percent).

Moreover, the majority of the respondents held middle-managerial position (i.e. senior manager or manager) with 71.5 percent, while the remaining 28.5 percent held top managerial position (i.e. owner, CEO, director). Even though 108 respondents (51.4 percent) only had five years or less of experience in the Halal food industry, a considerable portion of the respondents (102 respondents; 48.5 percent) still possess reasonable experience. 


\subsection{Measurement Model Evaluation}

To evaluate the PLS-SEM measurement model, four types of systematic assessments were conducted. It should be highlighted that in this paper, a reflective measurement model was applied instead of a formative measurement model. Following Hair et al. (2014a) assessments on reflectively measured construct, the four reliability and validity analyses were a) internal consistency (composite reliability), b) indicator reliability, c) convergent validity (average variance extracted, $A V E$ ), and d) discriminant validity. For this study, there were five exogenous constructs, namely human resource (HUM), infrastructure and equipment (INF), production process (PRO), marketing function (MAR), and logistics and distribution (LOG), and two endogenous constructs, specifically operational performance (OPER) and financial performance (FPER).

Firstly, the internal consistency reliability was evaluated by assessing the composite reliability (CR). CR was chosen because the traditional use of Cronbach's alpha (CA) has the tendency to underestimate the internal consistency reliability (Hair et al., 2014a). To assess CR, Hair et al. (2014a, 2011) suggested a value of 0.70 and above to indicate internal consistency. As shown in Table 2, the CR values of this study were above the 0.70 threshold ranging between 0.899 (MAR) and 0.943 (OPER). It is necessary to specify that a CR value of more than 0.95 could potentially indicate a common method bias (Straub et al., 2004).

Table 2: Internal Consistency and Indicator Reliability

\begin{tabular}{|c|c|c|c|c|}
\hline Construct & Indicator & Loading & $\mathrm{CR}$ & $C A$ \\
\hline \multirow[t]{5}{*}{ HUM } & HUM1 & 0.893 & 0.940 & 0.920 \\
\hline & HUM2 & 0.855 & & \\
\hline & HUM3 & 0.897 & & \\
\hline & HUM4 & 0.863 & & \\
\hline & HUM5 & 0.840 & & \\
\hline \multirow[t]{5}{*}{ INF } & INF1 & 0.772 & 0.900 & 0.860 \\
\hline & INF2 & 0.719 & & \\
\hline & INF3 & 0.867 & & \\
\hline & INF4 & 0.846 & & \\
\hline & INF5 & 0.792 & & \\
\hline \multirow[t]{5}{*}{ PRO } & PRO1 & 0.806 & 0.923 & 0.900 \\
\hline & PRO2 & 0.873 & & \\
\hline & PRO3 & 0.905 & & \\
\hline & PRO4 & 0.861 & & \\
\hline & PRO5 & 0.783 & & \\
\hline
\end{tabular}


Table 2: Internal Consistency and Indicator Reliability (continued)

\begin{tabular}{|c|c|c|c|c|}
\hline Construct & Indicator & Loading & $\mathrm{CR}$ & $\mathrm{CA}$ \\
\hline \multirow[t]{5}{*}{ MAR } & MAR1 & 0.797 & 0.899 & 0.862 \\
\hline & MAR2 & 0.759 & & \\
\hline & MAR3 & 0.842 & & \\
\hline & MAR4 & 0.793 & & \\
\hline & MAR5 & 0.810 & & \\
\hline \multirow[t]{5}{*}{ LOG } & LOG1 & 0.821 & 0.922 & 0.893 \\
\hline & LOG2 & 0.893 & & \\
\hline & LOG3 & 0.847 & & \\
\hline & LOG4 & 0.896 & & \\
\hline & LOG5 & 0.727 & & \\
\hline \multirow[t]{8}{*}{ OPER } & OPER1 & 0.816 & 0.943 & 0.932 \\
\hline & OPER2 & 0.818 & & \\
\hline & OPER3 & 0.813 & & \\
\hline & OPER4 & 0.804 & & \\
\hline & OPER5 & 0.820 & & \\
\hline & OPER6 & 0.852 & & \\
\hline & OPER7 & 0.823 & & \\
\hline & OPER8 & 0.838 & & \\
\hline \multirow[t]{4}{*}{ FPER } & FPER1 & 0.798 & 0.936 & 0.909 \\
\hline & FPER2 & 0.881 & & \\
\hline & FPER3 & 0.924 & & \\
\hline & FPER4 & 0.938 & & \\
\hline
\end{tabular}

Note: CR (Composite Reliability); CA (Cronbach's Alpha); AVE (Average Variance Extracted)

Secondly, indicator reliability was analysed to measure the outer loading variances that explained the underlying construct (Hair et al., 2014a). In order to demonstrate substantial reliability, the outer loading of greater than 0.70 is recommended (Hair et al., 2014a, 2011). The indicator loadings for all exogenous and endogenous constructs in this study (Table 2) indicated that each construct sufficiently captures a common concept. Thus, no indicator was removed and the measurement model was suitable for further analysis.

Thirdly, to evaluate the convergent validity, this paper refers to the value of average variance extracted (AVE). An AVE is "the grand mean value of the squared loadings of the indicators associated with the construct" (Hair et al., 2014a), which represent the collectiveness of a particular construct. To achieve a significant convergent validity, Hair et al. (2011) recommended an AVE value of more than 0.50. The AVE values for each construct in this study are presented in Table 3, which reveal the value of above 0.50 . Hence, these AVE values signify that more than half of the construct variances were explained by their respective indicators. 
Table 3: Convergent and Discriminant Validity

\begin{tabular}{ccccccccc}
\hline & AVE & FPER & HUM & INF & LOG & MAR & OPER & PRO \\
\hline FPER & 0.786 & 0.886 & & & & & & \\
HUM & 0.757 & 0.402 & 0.870 & & & & & \\
INF & 0.641 & 0.298 & 0.670 & 0.800 & & & & \\
LOG & 0.704 & 0.487 & 0.603 & 0.662 & 0.840 & & & \\
MAR & 0.641 & 0.354 & 0.486 & 0.569 & 0.592 & 0.800 & & \\
OPER & 0.677 & 0.677 & 0.568 & 0.624 & 0.661 & 0.572 & 0.822 & \\
PRO & 0.717 & 0.349 & 0.646 & 0.765 & 0.610 & 0.516 & 0.574 & 0.848 \\
\hline
\end{tabular}

Lastly, discriminant validity was measured to decisively distinguish a construct from one another in a path model (Hair et al., 2014a). This paper evaluates discriminant validity by assessing the Fornell and Larcker (1981) criterion, as suggested by Hair et al. (2011). The result for discriminant validity is tabulated in Table 3. As shown in Table 3, the square root of each construct's' AVE (in italic) are greater than its individual correlation with any other construct. This proves that every construct in this study are truly unique and individually measured. Therefore, based on the reliability and validity evaluations of the measurement model, this paper proves that the questionnaire deployed for this study satisfied every empirical measurement.

\subsection{Hierarchical Component Model}

Before proceeding to examine the structural model, it is important to note that a Hierarchical Component Model (HCM) procedure was performed. HCM was performed as the model could be operationalised at a greater level of generalisation (Hair et al., 2014a). HCM is often used in PLS-SEM as an approach to summarise multiple lower-order constructs (LOC) into a single multidimensional higher-order construct (HOC) (Becker et al., 2012; Ringle et al. 2012). In this study, the Reflective-Formative (Type II) HCM was used. To perform HCM for PLS-SEM, the paper observed the two-stage approach suggested by Hair et al. (2014a), Becker et al. (2012), and Ringle et al. (2012).

In the first-stage approach, the LOCs of HUM, INF, PRO, MAR, and LOG were combined together to create a HOC, identified as Halal Food Certification (HFC). Then, a repeated indicator approach was performed (Hair et al., 2014a; Becker et al., 2012). This approach assigned the LOCs reflective indicators to the HFC construct. This means that the HFC has 25 similar reflective indicators as the LOCs. Subsequently, in the second-stage approach, the LOCs latent variable scores were assigned as the manifest variable for the HFC construct. In this stage, the LOCs are now the indicators for HFC. 
Once the HCM was performed, the PLS path model is more parsimonious and identical to the proposed theoretical model (Figure 1). The next step was to evaluate the HCM. According to Hair et al. (2014a, p. 231), "the same measurement model evaluation criteria apply to the HOC as for any other construct in the PLS path model". Correspondingly, the results for the newly developed $\mathrm{HCM}$ is presented in Table 4. The assessment criteria shown in Table 4 indicate that the HCM satisfies every measurement model reliability and validity evaluations, and therefore, it is appropriate for structural model evaluation.

Table 4: Reliability and Validity of HOC

\begin{tabular}{ccccccc}
\hline \multirow{2}{*}{ Construct } & \multicolumn{2}{c}{ Reliability } & \multicolumn{4}{c}{ Validity } \\
\cline { 2 - 7 } & CR & CA & AVE & FPER & HFC & OPER \\
\hline FPER & 0.936 & 0.909 & 0.786 & 0.886 & & \\
HFC* & 0.918 & 0.887 & 0.691 & 0.457 & 0.831 & \\
OPER & 0.944 & 0.932 & 0.677 & 0.680 & 0.721 & 0.822 \\
\hline
\end{tabular}

Note: *HFC construct is a HOC (where HUM, INF, PRO, MAR, and LOG constructs are the LOCs)

\subsection{Structural Model Evaluation}

Having sufficiently evaluated the measurement model, this part of the paper now analyses the structural model. Structural model evaluation involves two important assessments, specifically the coefficient of determination $\left(R^{2}\right)$ and predictive relevance analyses $\left(Q^{2}\right)$ (Hair et al., 2011). The coefficient of determination measures the predictive accuracy of the exogenous constructs combined effects on the endogenous constructs. As a rule of thumb, Hair et al. (2014a and 2011 ) indicated that $R^{2}$ value of $0.25,0.50$, and 0.75 signify a weak, moderate, and substantial predictive accuracy. For this study, the $\mathrm{R}^{2}$ value for OPER is 0.520 while FPER is 0.463 . The findings imply that the HFC construct moderately predicts 52 percent of the variance of OPER construct. Likewise, the OPER construct moderately explains 46.3 percent of the variance in FPER the construct.

To measure the predictive relevance, the $\mathrm{Q}^{2}$ value was obtained using the blindfolding technique (Hair et al., 2014a). A blindfolding technique was performed to obtain cross-validated redundancy measures for each endogenous constructs. $A Q^{2}$ value of larger than zero for an endogenous construct is desirable. As a measure of predictive relevance, the values of $0.35,0.15$, and 0.02 indicate that an exogenous construct has a large, medium, and small predictive relevance on an endogenous construct (Hair et al., 2011). In this study, the $Q^{2}$ for FPER was 0.352 while OPER was 0.353 . Therefore, the resulting $Q^{2}$ values of more than zero signify that the HFC exogenous construct has a large predictive relevance for the OPER and FPER endogenous constructs. 


\subsection{Hypotheses Testing}

In order to test the three proposed hypotheses, the significant relationships of each path coefficients are assessed. A bootstrapping technique with 5000 resampling and a two-tailed test was performed. The results for hypothesis $\mathrm{H}_{1}$ and $\mathrm{H}_{2}$ are shown in Table 5 . In Table 5, the results revealed that Halal food certification had a positive, strong (path coefficient $=0.721$ ) and significant (t-statistics $=19.824$ ) relationship with operational performance, thus $\mathrm{H}_{1}$ is supported. Furthermore, the results shown in Table 5 also indicate that the relationship between operational performance and financial performance was positively significant (t-statistics $=14.863$ ), and therefore, $\mathrm{H}_{2}$ is supported.

Table 5: Hypotheses Testing

\begin{tabular}{ccccccc}
\hline Hypothesis & Path & $\begin{array}{c}\text { Path } \\
\text { Coefficeint }\end{array}$ & $\begin{array}{c}\text { Standard } \\
\text { Error }\end{array}$ & $p$-value & t-value & Decision \\
\hline $\mathrm{H}_{1}$ & HFC $\rightarrow$ OPER & 0.721 & 0.036 & $0.000^{*}$ & 19.824 & Support \\
$\mathrm{H}_{2}$ & OPER $\rightarrow$ FPER & 0.680 & 0.046 & $0.000^{*}$ & 14.863 & Support
\end{tabular}

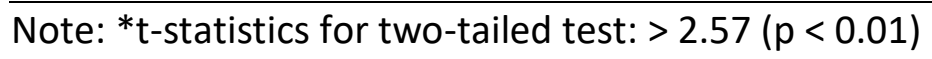

To test for mediation, this paper refers to Hair's et al. (2014a) procedures. Specifically, the indirect relationship via OPER mediator effects the direct relationship from HFC to FPER in the mediator model. Additionally, the variance accounted for (VAF) was used to determine the size of indirect effect in relation to the total effect (Hair et al., 2014a). The result for the operational performance mediating the relationship between Halal food certification and financial performance is shown in Table 6.

Table 6: Analysis of Mediating Effect

\begin{tabular}{ccccccc}
\hline Hypothesis & Path & $\begin{array}{c}\text { Direct } \\
\text { Effect }\end{array}$ & $\begin{array}{c}\text { Indirect } \\
\text { Effect }\end{array}$ & $\begin{array}{c}\text { Total } \\
\text { Effect }\end{array}$ & VAF & Decision \\
\hline & HFC $\rightarrow \begin{array}{l}\text { O OPER } \rightarrow \\
\text { FPER }\end{array}$ & $0.468^{*}$ & $0.525^{*}$ & $0.993^{*}$ & $\begin{array}{c}0.529 \approx 53 \% \\
\text { (Partial Mediation) }\end{array}$ & Support
\end{tabular}

Note: OPER is the mediating construct; VAF is equal to indirect effect divided by total effect; ${ }^{*} p$ $<0.01$ 
Based on the results shown in Table 6, given that the direct, indirect and total effects are significant $(p<0.01)$, and that the VAF value indicates 0.529 , it gives the interpretation that the OPER construct partially (53 percent) moderates the relationship between HFC and FPER. In other words, operational performance (OPER) moderately absorbs Halal food certification (HFC) variable's effect on financial performance (FPER). Therefore, this supports the $\mathrm{H}_{3}$ hypothesis that operational performance mediates the relationship between Halal food certification and financial performance.

\section{Discussion and Conclusion}

The present study was designed to explore the relationship between Halal food certification and business performance. For this research, the business performance variable is the combination of operational and financial performances. Additionally, three hypotheses were proposed and a theoretical framework was developed (Figure 1).

The first hypothesis in this study sought to establish the link between Halal food certification and operational performance. Based on the results of this study, it is proven that Halal food certification has a positive and significant relationship with operational performance. Given that the association between Halal food certification and operational performance was sporadically mentioned and empirical evidence was lacking, the findings from this study offer a new insight that a religion-based certification has similar aspects and relation with operational performance. This further strengthens previous notions that Halal food certification is a type of food safety certification and the safety, quality, hygienic, and control attributes are consistent with the likes of HACCP or ISO 22000 (Demirci et al., 2016; Talib et al., 2015; Nawi and Nasir, 2014; Kohilavani et al., 2013).

Furthermore, the results emerged from this study are consistent with those of Chen et al. (2015), Escanciano and Santos-Vijande (2014), Kafetzopoulos and Gotzamani (2014), Macheka et al. (2013), Karaman et al. (2012), and Mensah and Julien (2011) who demonstrated that the implementation of food certification, in this case the MS1500, positively influence operational performance. Hence, this study further contributes to the growing body of Halal food certification literature and advances the understandings of the benefits from Halal food certificate implementation.

The second hypothesis in this study was intended to establish the positive relationship between operational and financial performance. The empirical evidence from this study revealed that there is a positive and significant relationship between operational and financial performance. The support of the second hypothesis substantiates the findings of Kafetzopoulos and Gotzamani (2014), who suggested that operational performance generates a significant 
contribution to financial performance. It can thus be suggested that the implementation of Halal food certification would potentially impact financial performance.

For the third hypothesis, this study postulates that operational performance mediates the relationship between Halal food certification and financial performance. Evidence from this study showed that operational performance was in fact a mediating factor between the Halal food certification and financial performance relationship. Although past studies (Kafetzopoulos and Gotzamani, 2014; Psomas et al., 2013) did not study the mediating role of operational performance, the findings from this study offer a newer and an alternative perspective. This paper argues that in addition to the operational performance of improved Halal food integrity, superior product quality and safety, and greater market shares, Halal food certification may play a central role in improving financial performance. For example, it could be argued that, due to the achievement in greater market shares (operational performance), this could lead to potential financial performance that includes sales growth or larger net profit. Taken together, the overall findings confirm the association of previously unconnected variables between Halal food certification and business performance.

Moving forward, the empirical evidence of this study suggests that business performance can be achieved through Halal food certificate implementation. However, it is important to bear in mind that business performance would not materialise if Halal food certification procedures and executions are merely 'for show'. Managers should be mindful that Halal food certification for the sake of appearance rather than for operational and financial achievements would not only cause unsustainable business operations but also compromised the integrity of Halal food products.

In terms of theoretical contribution, this study provides a framework for the connection between Halal food certification and business performance. This study further ratifies the suitability and relevance of the RBV concept in certification research (Talib et al., 2016b; Fikru, 2014). Besides, by applying the concept of RBV as the basis of research framework, the findings of this study enhanced the understanding of the Halal food certification integral function towards sustainable business. It is hoped that the empirical evidence from this study would direct managers' attention on ensuring the efficient implementation of MS1500 as it is capable of affecting food companies' operations and bottom lines.

The insights gained from this study could entice more food companies to implement Halal food certification, particularly the MS1500. Despite its exploratory nature, this study informs managers that Halal food certification can be utilised as a tool to gain superior business performance. For instance, with Halal food certification, food companies have the potential to improve their productivity and standardising internal operations. Furthermore, improved operational performance would then contributes to sales and profit growth. Evidently, the 
prospect of improved business performance could potentially persuade non-certified food companies to become Halal certified. Likewise, the knowledge gained from this study could be useful to foreign food companies and managers who wish to venture into the Malaysian Halal food industry. The ability to obtain authorised and recognised MS1500 would not only facilitate the entry into the Malaysian food industry, it also alleviates the access to the highly lucrative international Halal food industry of more than a billion consumers worldwide.

The generalisability of this study is subjected to certain limitations. As the samples were limited to Malaysian MS1500 certified food manufacturers, and because there are numerous Halal food certifications from various authorities and agencies, the relation with business performance might vary. Hence, future research on other established Halal certification from notable authorities (i.e. Islamic Religions Council of Singapore, HalMQ; Indonesian Council of Ulama, HAS 23000) is encouraged in order to reach more comprehensive understandings on Halal certification relation with business performance. Additionally, the empirical evidence and the supported hypotheses are based on a cross-section of the current environment. Thus, the study does not observe the magnitude of the relationship between Halal food certification and business performance. Therefore, a longitudinal research that scrutinises the proposed relationships over a period of time should be an agenda for future studies. Nevertheless, the present study provides a solid platform for future scholars to work on.

\section{References}

Abdul, M., Ismail, H., Hashim, H. and Johari, J. (2008), "SMEs and Halal certification", East Coast Economic Region (ECER) Regional Conference 2008, UPENA, Kota Bharu, Kelantan, pp. 609618.

Aziz, Y.A. and Chok, N.V. (2013), "The role of Halal awareness, Halal certification, and marketing components in determining Halal purchase intention among non-Muslims in Malaysia: A structural equation modeling approach", Journal of International Food \& Agribusiness Marketing, Vol. 25 No. 1, pp. 1-23.

Badruldin, B., Mohamed, Z., Sharifuddin, J., Rezai, G., Mahir Abdullah, A., Abd Latif, I. and Ghazali Mohayidin, M. (2012), “Clients' perception towards JAKIM service quality in Halal certification", Journal of Islamic Marketing, Vol. 3 No. 1, pp. 59-71.

Barney, J. (1991), "Firm resources and sustained competitive advantage", Journal of Management, Vol. 17 No. 1, pp. 99-120. 
Becker, J.M., Klein, K. and Wetzels, M. (2012), "Hierarchical latent variable models in PLS-SEM: Guidelines for using reflective-formative type models", Long Range Planning, Elsevier Ltd, Vol. 45 No. 5-6, pp. 359-394.

Chen, E., Flint, S., Perry, P., Perry, M. and Lau, R. (2015), "Implementation of non-regulatory food safety management schemes in New Zealand: A survey of the food and beverage industry", Food Control, Vol. 47, pp. 569-576.

Chow-Chua, C., Goh, M. and Boon Wan, T. (2003), "Does ISO 9000 certification improve business performance?", International Journal of Quality \& Reliability Management, Vol. 20 No. 8, pp. 936-953.

Demirci, M.N., Soon, J.M. and Wallace, C.A. (2016), "Positioning food safety in Halal assurance", Food Control, Vol. 70, pp. 257-270.

Escanciano, C. and Santos-Vijande, M.L (2014), "Implementation of ISO-22000 in Spain: Obstacles and key benefits", British Food Journal, Vol. 116 No. 10, p. 1581.

Feng, M., Terziovski, M. and Samson, D. (2008), "Relationship of ISO 9001:2000 quality system certification with operational and business performance: A survey in Australia and New Zealand-based manufacturing and service companies", Journal of Manufacturing Technology Management, Vol. 19 No. 1, pp. 22-37.

Fikru, M.G. (2014), “Firm level determinants of international certification: Evidence from Ethiopia", World Development, Vol. 64, pp. 286-297.

Fischer, J. (2012), "Branding halal: A photographic essay on global Muslim markets", Anthropology Today, Vol. 28 No. 4, pp. 18-21.

Fischer, J. (2016), "Manufacturing Halal in Malaysia”, Contemporary Islam, Vol. 10 No. 1, pp. 3552.

Fornell, C. and Larcker, D.F. (1981), "Evaluating structural equation models with unobservable variables and measurement error", Journal of Marketing Research, Vol. 18 No. 1, pp. 3950.

Hair, J.F., Hult, J.G.T.M., Ringle, C.M. and Sarstedt, M. (2014a), A Primer on Partial Least Squares Structural Equation Modeling (PLS-SEM), Sage Publication, Singapore.

Hair, J.F., Ringle, C.M. and Sarstedt, M. (2011), "PLS-SEM: Indeed a silver bullet", Journal of Marketing Theory and Practice, Vol. 19 No. 2, pp. 139-152. 
Hair, J.F., Sarstedt, M., Hopkins, L. and G. Kuppelwieser, V. (2014b), "Partial least squares structural equation modeling (PLS-SEM): An emerging tool for business research", European Business Review, Vol. 26 No. 2, pp. 106-121.

Hair, J.F., Sarstedt, M., Pieper, T.M. and Ringle, C.M. (2012a), "The use of partial least squares structural equation modeling in strategic management research: A review of past practices and recommendations for future applications", Long Range Planning, Elsevier Ltd, Vol. 45 No. 5-6, pp. 320-340.

Hair, J.F., Sarstedt, M., Ringle, C.M. and Mena, J.A. (2012b), "An assessment of the use of partial least squares structural equation modeling in marketing research", Journal of the Academy of Marketing Science, Vol. 40 No. 3, pp. 414-433.

Haque, A., Sarwar, A., Yasmin, F., Tarofder, A.K. and Hossain, M.A. (2015), "Non-Muslim consumers' perception toward purchasing halal food products in Malaysia", Journal of Islamic Marketing, Vol. 6 No. 1, pp. 133-147.

Kafetzopoulos, D.P. and Gotzamani, K.D. (2014), "Critical factors, food quality management and organizational performance", Food Control, Vol. 40, pp. 1-11.

Karaman, A.D., Cobanoglu, F., Tunalioglu, R. and Ova, G. (2012), "Barriers and benefits of the implementation of food safety management systems among the Turkish dairy industry: A case study", Food Control, Vol. 25, pp. 732-739.

Kohilavani, Zzaman, W., Febrianto, N.A., Zakariya, N.S., Abdullah, W.N.W. and Yang, T.A. (2013), "Embedding Islamic dietary requirements into HACCP approach", Food Control, Vol. 34, pp. 607-612.

Lever, J. and Miele, M. (2012), "The growth of halal meat markets in Europe: An exploration of the supply side theory of religion". Journal of Rural Studies, Vol. 28 No. 4, pp. 528-537.

Macheka, L., Manditsera, F.A., Ngadze, R.T., Mubaiwa, J. and Nyanga, L.K. (2013), "Barriers, benefits and motivation factors for the implementation of food safety management system in the food sector in Harare Province, Zimbabwe", Food Control, Vol. 34, pp. 126-131.

Marzuki, S.Z.S., Hall, C.M. and Ballantine, P.W. (2012), "Restaurant managers' perspectives on Halal certification", Journal of Islamic Marketing, Vol. 3 No. 1, pp. 47-58.

Mensah, L.D. and Julien, D. (2011), "Implementation of food safety management systems in the UK", Food Control, Vol. 22, pp. 1216-1225. 
Mohamed, Z., Shamsudin, M.N. and Rezai, G. (2013), "The effect of possessing information about Halal logo on consumer confidence in Malaysia", Journal of International Food \& Agribusiness Marketing, Vol. 25 No. sup1, pp. 73-86.

Nawi, N.M. and Nasir, N.I.M. (2014), “Consumers' attitude toward the food safety certificate (FSC) in Malaysia", Journal of Food Products Marketing, Vol. 20 No. sup1, pp. 140-150.

Noordin, N., Hashim, M. and Samicho, Z. (2009), "Value chain of Halal certification system: A case of the Malaysia Halal industry", European and Mediterranean Conference on Information Systems 2009 (EMCIS2009), pp. 1-14.

Noordin, N., Md Noor, N.L. and Samicho, Z. (2014), "Strategic approach to Halal certification system: An ecosystem perspective", Procedia-Social and Behavioral Sciences, Vol. 121, pp. 79-95.

Psomas, E.L., Pantouvakis, A. \& and Kafetzopoulos, D.P. (2013), "The impact of ISO 9001 effectiveness on the performance of service companies", Managing Service Quality, Vol. 23 No. 2, pp. 149-164.

Rafiki, A. and Wahab, K. A. (2016), "The human capital and the obtainment of halal certification", Journal of Islamic Marketing, Vol. 7 No. 2, pp. 134-147.

Rahman, A.A., Singhry, H.B., Hanafiah, M.H. and Abdul, M. (2016), "Influence of perceived benefits and traceability system on the readiness for Halal Assurance System implementation among food manufacturers", Food Control, Vol. 73, pp. 1318-1326.

Rahman, R.A., Rezai, G., Mohamed, Z., Shamsudin, M.N. and Sharifuddin, J. (2013), "Malaysia as global Halal hub: OIC food manufacturers' perspective", Journal of International Food \& Agribusiness Marketing, Vol. 25 No. sup1, pp. 154-166.

Rezai, G., Mohamed, Z. and Shamsudin, M.N. (2015), "Can Halal be sustainable? Study on Malaysian consumers' perspective", Journal of Food Products Marketing, Vol. 21 No. 6, pp. 654-666.

Riaz, M.N. and Chaudry, M.M. (2004), Halal Food Production, CRC Press, Boca Raton, FL.

Ringle, C.M., Sarstedt, M. and Straub, D. (2012), "A critical look at the use of PLS-SEM in MIS Quarterly", MIS Quarterly, Vol. 36 No. 1, pp. 3-14.

Ringle, C.M., Wende, S. and Will, S. (2005), "SmartPLS 2.0.M3", SmartPLS, Hamburg, available at: http://www.smartpls.de. 
Sampaio, P., Saraiva, P. \& and Rodrigues, A. (2009), "ISO 9001 certification research: questions, answers and approaches", International Journal of Quality \& Reliability Management, Vol. 26 No. 1, pp. 38-58.

Straub, D., Boudreau, M.-C. and Gefen, D. (2004), "Validation guidelines for IS positivist", Communications of the Association for Information Systems, Vol. 13 No. 24, pp. 380-427.

Sum, C.-C., Teo, C.-B. and Ng, K.-K. (2001), "Strategic logistics management in Singapore", International Journal of Operations \& Production Management, Vol. 21 No. 9, pp. 12391260.

Talib, M.S.A., Hamid, A.B.A. and Ai Chin, T. (2015), "Motivations and limitations in implementing Halal food certification: a Pareto analysis", British Food Journal, Vol. 117 No. 11, pp. 26642705.

Talib, M.S.A., Sawari, S.S.M., Hamid, A.B.A. and Ai Chin, T. (2016a), "Emerging Halal food market: an Institutional Theory of Halal certificate implementation", Management Research Review, Vol. 39 No. 9, pp. 987-997.

Talib, M.S.A., Hamid, A.B.A. and Ai Chin, T. (2016b), "Can Halal certification influence logistics performance?", Journal of Islamic Marketing, Vol. 7 No. 4, pp. 461-475.

Tieman, M., van der Vorst, J.G.A.J. and Che Ghazali, M. (2012), "Principles in halal supply chain management", Journal of Islamic Marketing, Vol. 3 No. 3, pp. 217-243.

Verbeke, W., Rutsaert, P., Bonne, K. and Vermeir, I. (2013), "Credence quality coordination and consumers' willingness-to-pay for certified halal labelled meat", Meat Science, Vol. 95 No. 4, pp. 790-797.

Zailani, S., Kanapathy, K., Iranmesh, M. and Tieman, M. (2015), "Drivers of Halal orientation strategy among Halal food firms", British Food Journal, Vol. 117 No. 8, pp. 148-163.

Note: This is the final accepted version. Any mistakes are the authors'. 